\title{
ASAS PROPORSIONAL DALAM PERJANJIAN WARALABA (FRANCHISE)
}

Oleh :

\author{
Siti Rahayu
}

Fakultas Hukum Universitas Merdeka Surabaya e-mail: sitirahayu1225@gmail.com

\section{Supartini}

Fakultas Ekonomi Universitas Merdeka Surabaya

e-mail: supartini59@gmail.com

\section{Sinarianda Kurnia Hartanti}

Fakultas Hukum Universitas Merdeka Surabaya

e-mail: sinariandakurnia@gmail.com

\begin{abstract}
ABSTRAK
Waralaba adalah persetujuan atas pemberian hak atas istimewaan untuk memasarkan suatu barang atau jasa dari pemilik kepada pihak lain yang diatur dalam suatu aturan permainan tertentu. Waralaba juga digunakan dalam Peraturan Pemerintah Republik Indonesia (PPRI) Nomor 16 Tahun 1997 adalah kata lain dari franchise. Dalam Peraturan Pemerintah Republik Indonesia (PPRI) Nomor 16 Tahun 1997 tersebut sebagai kata lain dari franchisor disebut pemberi waralaba dan untuk kata lain dari franchise disebut penerima waralaba. Definisi mengenai waralaba ini kemudian berkembang dengan bermacam-macam pengertian namun dengan prinsip yang sama yakni adanya pemberian hak menggunakan atau memanfaatkan hak milik intelektual dari pihak pemberi waralaba oleh penerima waralaba dalam suatu jaringan pemasaran.
\end{abstract}

Kata kunci : asas proporsional, perjanjian, waralaba.

\section{PENDAHULUAN}

Untuk pertama kali Franchise atau nama lain dari Waralaba, ${ }^{1}$ walaupun waralaba atau usaha waralaba sudah berkembang sejak \pm 13 (tiga belas) tahun yang lalu. Namun sampai hari ini tidak ada suatu peraturan yang mengatur tentang usaha waralaba yang menyangkut isi dan klausa dalam perjanjian waralaba dan segala aspek hukum yang terkait didalamnya.

Peraturan yang ada pada saat ini hanya Peraturan Pemerintah

1 Amir Karamoy, Sukses Usaha Lewat Waralaba, Jurnalindo Aksara Grafika, Jakarta, 1996, hal.3. 
Republik Indonesia (PPRI) Nomor 16 Tahun 1997 berserta peraturan pelaksanaannya yakni Keputusan Menteri Perindustrian dan Perdagangan Nomor 31/MDAG/PER/8/2008 tentang Penyelenggaraan Waralaba. Namun Peraturan Pemerintah tersebut bukanlah mengatur tentang hubungan hukum pihak-pihak dalam perjanjian waralaba tetapi hanya mengatur ketentuan dan tata cara pelaksanaan pendaftaran usaha waralaba. Padahal sebenarnya Pemerintah berkeinginan untuk mengembangkan usaha waralaba untuk mendorong kemitraan dan pembinaan pengusaha kecil dan menengah sebagaimana yang dikehendaki oleh Undang-undang Nomor 19 Tahun 1995.

Karena Pemerintah melihat bahwa konsep waralaba dapat merupakan salah satu cara untuk meningkatkan kegiatan ekonomi, pemerataan dan menciptakan lapangan kerja.

Tidakkah Pemerintah perlu melindungi kepentingan masyarakat yang awam terhadap aspek hukum dari suatu perjanjian dengan menetapkan peraturan-peraturan dan persyaratan-persyaratan serta pengawasan terhadap berlakunya peraturan-peraturan berdasarkan pada ketentuan-ketentuan yang baku, tidak saja meliputi perjanjian waralaba, tapi juga menyangkut perjanjian kredit perbankan dan banyak lagi perjanjian-perjanjian yang dibuat berdasarkan ketentuan yang baku.

Yang dimaksudkan dengan franchise atau waralaba adalah hakhak istimewa untuk memproduksi sesuatu barang yang diberikan oleh Pemerintah terhadap perorangan atau perusahaan yang hak-haknya tersebut tadinya belum dimiliki.

Dari uraian di atas dapat dijelaskan bahwa perjanjian waralaba adalah :

1. Perjanjian antara pembeli waralaba (franchisor) dengan penerima waralaba (franchise).

2. Menyangkut suatu produk atau jasa dari pemiliknya (franchisor) kepada pihak lain (franchise) untuk menjual produk atau jasa tersebut dengan memberi nama, merk atau hak milik intelektual dari si pemberi waralaba (franchisor).

3. Isi dari perjanjian waralaba diatur atau ditetapkan oleh peraturan-peraturan

Pemerintah dan negara bagian.

Di negara Indonesia untuk saat ini waralaba, usaha waralaba atau perjanjian waralaba belum diatur dalam undang-undang atau peraturan yang setara dengan undang-undang. Sedangkan Peraturan Pemerintah Republik Indonesia (PPRI) Nomor 16 Tahun 1997 hanya mengatur tentang syarat-syarat pendaftaran dari perjanjian waralaba bagi penerima waralaba (franchise) untuk memperoleh Surat Tanda Pendaftaran Usaha Waralaba (untuk selanjutnya disebut STPUW). Peraturan pelaksana dari Peraturan Pemerintah Republik Indonesia (PPRI) Nomor 16 Tahun 1997 terdapat dalam Keputusan Menteri Perindustrian dan Perdagangan Republik Indonesia tentang Ketentuan dan Tata Cara Pelaksanaan Pendaftaran Waralaba Nomor 259/MPP/KEP/7/1997 tanggal 30 Juli 1997 kemudian 
disingkat dengan SK DEPERINDAG Nomor 259.

Dalam Pasal 1 Peraturan Pemerintah Republik Indonesia (PPRI) Nomor 16 Tahun 1997 dirumuskan tentang pengertian waralaba, pemberi waralaba dan penerima waralaba. Sedangkan dalam Pasal 2 dari Peraturan Pemerintah tersebut ditetapkan bahwa :

1. Waralaba diselenggarakan berdasarkan perjanjian tertulis antara pemberi waralaba dan penerima waralaba.

2. Perjanjian waralaba dibuat dalam bahasa Indonesia dan terhadapnya berlaku hukum Indonesia.

Pada skripsi ini penulis ingin menggarisbawahi tentang Pasal 2 dari Peraturan Pemerintah Republik Indonesia (PPRI) Nomor 16 Tahun 1997 yang menjadi pokok permasalahan dalam penulisan ini, khususnya mengenai kewajiban diberlakukannya hukum Indonesia dalam perjanjian waralaba.

Perlu dicatat bahwa perjanjian waralaba yang pada saat ini mengenai waralaba sendiri belum diatur oleh undang-undang atau peraturan yang setara dengan undang-undang, terjadi baik antara pengusaha asing dan pengusaha domestik terutama untuk produk makanan atau minuman, barang-barang produksi dan jasa.

Adapun perjanjian waralaba yang dibuat khususnya antara pengusaha asing (yang tunduk pada hukum asing) dengan pengusaha domestik berdasarkan pada asas kebebasan berkontrak mengandung pengertian bahwa pihak-pihak bebas dalam menentukan pilihan hukum yang disepakati (Choice of Law).
Dengan ditetapkannya dalam

Peraturan Pemerintah Republik Indonesia (PPRI) Nomor 16 Tahun 1997 bahwa perjanjian waralaba harus dibuat berdasarkan hukum Indonesia maka Pemerintah bermaksud untuk membatasi asas kebebasan berkontrak dengan tujuan melindungi kepentingan pengusaha domestik sekaligus menawarkan hukum Indonesia dalam perjanjian perdagangan yang mempunyai unsur asing.

Namun disamping hal terurai di atas maka perlu pula dipermasalahkan bahwa apakah Peraturan Pemerintah Republik Indonesia (PPRI) Nomor 16 Tahun 1997 yang hanya berupa Peraturan Pemerintah bukan suatu undangundang tidak bertentangan dengan Pasal 17 Algemene Bepalingen Van Wetgering (untuk selanutnya disebut $\mathrm{AB}$ ) yang berbunyi :

"Terhadap barang-barang yang tidak bergerak berlakulah undang-undang dari negara atau tempat dimana barang-barang itu ada".

Karena seandainya Pemerintah ingin memberlakukan hukum Indonesia dalam perjanjian waralaba dan mencabut ketentuan dalam Pasal 17 AB, maka apakah Peraturan Pemerintah bisa mencabut ketentuan dalam $\mathrm{AB}$ yang setara dengan undang-undang, hal ini menyangkut hirarki dalam perundang-undangan.

Dengan demikian dalam perjanjian waralaba yang menyangkut barang-barang yang tidak ebrgerak berdasarkan pada ketentuan dalam Pasal 17 AB berlaku hukum dimana barang tersebut berada. Sehingga 
tidak selalu harus hukum Indonesia untuk barang yang tidak bergerak.

Selanjutnya dalam membahas perjanjian waralaba disamping menyangkut asas-asas dalam hukum perjanjian maka perlu dibahas aspekaspek hukum perjanjian itu sendiri seperti aspek hukum hal cipta, paten dan merek, aspek hukum pajak, aspek alih teknologi dan aspek hukum ketenagakerjaan.

\section{PERMASALAHAN}

Dari hal yang telah diuraikan dalam artikel ini, maka yang ingin penulis teliti adalah :

1. Bagaimanakah batasan asas kebebasan berkontrak sehubungan dengan ketentuan bahwa perjanjian waralaba harus menggunakan hukum Indonesia?

2. Bagaimanakah peranan Pemerintah dalam turut menentukan batasan asas kebebasan berkontrak dalam perjanjian waralaba di Indonesia?

\section{METODOLOGI}

Penulisan artikel ini menggunakan metode deskriptif analisis yaitu metode yang menggambarkan dan menafsirkan bahan hukum yang telah disusun, serta menguraikan masalahnya yang kemudian dianalisa. Dengan metode ini diharapkan akan dapat diketahui ketentuan mana yang harus dipergunakan berkenaan dengan permasalahan yang dibahas dalam permasalahan artikel ini. Bahan hukum yang dipakai terdiri dari : Bahan hukum primer, yaitu bahan hukum dari peraturan perundangundangan yang berkaitan baik langsung maupun tidak langsung dengan topik penulisan artikel ini. Bahan hukum sekunder, yaitu bahan hukum yang diperoleh dari pendapat para sarjana, majalah, literatur, dan buku-buku.

\section{PEMBAHASAN}

\section{PERJANJIAN / KESEPAKATAN WARALABA DAN ASPEK HUKUMNYA}

Adanya hubungan dalam usaha waralaba akan melahirkan suatu perikatan yang lahir dari suatu perjanjian atau kontrak antara pemberi waralaba dengan penerima waralaba. Dimana Pasal 1320 KUHP Perdata menyatakan bahwa untuk sahnya suatu perjanjian harus memenuhi 4 (empat) syarat, yaitu :

1. Sepakat dari mereka yang mengikatkan diri.

2. Kecakapan untuk membuat perikatan.

3. Suatu hal tertentu.

4. Kausa yang diperbolehkan. Adapun syarat yang ke-1 dan ke-2 adalah merupakan syarat subyektif, yakni menyangkut diri orang yang bersangkutan. Sedangkan syarat yang ke-3 dan ke-4 adalah syarat obyektif, yakni yang menyangkut obyek dari perjanjian.

Syarat subyektif dan syarat obyektif seperti yang dicantumkan dalam Pasal 1320 KUH Perdata mengandung konsekwensi hukum yang berbeda. Dalam syarat subyektif, maka tidak dipenuhi salah satu dari syarat itu berakibat perjanjian batal demi hukum, artinya tidak perlu dimintakan pembatalan melalui Pengadilan. Sedangkan syarat obyektif, bila salah satu syarat tidak dipenuhi maka pembatalannya harus dimintakan. Tidak seketika batal 
sebagaimana halnya dengan syarat subyektif.

Bila seluruh syarat dalam Pasal 1320 KUH Perdata perjanjian tersebut mempunyai kekuatan hukum atau mengikat para pihak.

Pasal 1338 KUH Perdata menyatakan

"Setiap persetujuan yang dibuat secara sah berlaku sebagai undang-undang bagi mereka yang membuatnya. Persetujuan tidak dapat ditarik kembali kecuali atas sepakat pihak-pihak yang terikat didalamnya".

Selanjutnya dalam Pasal 1338 KUH Perdata menegaskan :

"Persetujuan tidak hanya mengikat untuk hal-hal yang dinyatakan didalamnya, tetapi juga untuk segala sesuatu yang menurut sifat persetujuan diharuskan oleh kesepakatan, kebiasaan dan undang-undang".

Dari sini terkandung makna bahwa setiap perjanjian mengandung asas-asas hukum yang harus diperhatikan untuk sahnya suatu perjanjian, dan asas-asas hukum yang dimaksud adalah :

\section{Asas Kebebasan Berkontrak}

Asas kebebasan berkontrak memberikan jaminan kepada setiap orang untuk membuat persetujuan sesuai dengan kehendaknya masingmasing yang terjelma dalam isi dari perjanjian diantara mereka. Kebebasan yang dimaksud bukanlah kebebasan tanpa batas. Artinya, kebebasan sepanjang tidak bertentang dengan undang-undang, kebiasaan, kesusilaan dan kepatutan yang berlaku. Misalnya, adalah tidak biasa dan tidak patut untuk menyuruh salah satu pihak untuk menandatangani perjanjian yang beberapa bagian dari isi perjanjian tersebut masih dikosongkan.

Dan juga adalah tidak biasa dan tidak patut bahkan bertentang dengan undang-undang bila salah satu pihak diminta menandatangani perjanjian di hadapan Notaris tanpa diterangkan dan dibacakan isi perjanjian tersebut.

Hal ini sering etrjadi dalam perjanjian baku atau perjanjian standar yang isi dan syarat dalam suatu perjanjian sudah tercetak rapi dalam satu format atau formulir. Sehingga pihak-pihak lain dalam perjanjian tersebut hanya mempunyai pilihan, ditandatangani atau tidak.

Perjanjian-perjanjian

semacam ini banyak terdapat atau hampir semuanya terjadi dalam perjanjian kredit perbankan, polis asuransi, perjanjian-perjanjian angkutan orang dan barang, serta lainlain perjanjian dengan isi yang sudah dibakukan.

Di negara Belanda, di tempat asalnya sebagian dari perundangundangan negara kita, syarat batalnya dari suatu perjanjian disamping ketentuan-ketentuan yang sudah ada, mengalami perkembangan yakni dengan apa yang disebut dengan Undue Influence atau dalam bahasa Belanda misbruik van Omstandigheden atau penyalahgunaan keadaan (atau penyalahgunaan kesempatan).

Yang dimaksud dengan penyalahgunaan keadaan bilamana suatu eprsetujuan atau eprjanjian dibuat atas dasar tekanan keadaan secara tidak adil, sehingga merupakan beban yang sangat berat dan merugikan terhadap salah satu pihak 
dengan menggunakan suatu kesempatan, yang oleh pihak lain sebenarnya tidak dikehendaki.

Di tempat asalnya yang memberlakukan "penyalahgunaan keadaan" sebagai salah satu syarat batal yakni di negara Belanda, berkembang 2 (dua) pendapat. Pertama, syarat batal karena penyalahgunaan keadaan dalam suatu persetujuan. Kedua, perjanjian digolongkan dalam kuasa yang tidak diperbolehkan menurut Pasal 1320 KUH Perdata atau syarat ke-4.

Namun sebagian pakar berpendapat termasuk pendapat dari A.Z. Asikin Kusumah Atmadja, ${ }^{2}$ bahwa penyalahgunaan keadaan tidak dapat digolongkan sebagai kuasa yang tidak diperbolehkan tapi lebih tepat digolongkan sebagai kehendak yang cacat yang dalam Pasal 1320 KUH Perdata diisyaratkan tentang "sepakat mereka yang mengikatkan dirinya dalam suatu persetujuan". Karena menurut beliau kuasa yang tidak cacat kehendak memiliki ciri yang berbeda dan tidak ada kaitannya dengan kehendak yang cacat.

Menggolongkan

penyalahgunaan keadaan sebagai salah satu bentuk cacat kehendak lebih sesuai dengan kebutuhan konstruksi hukum dalan hal seseorang yang dirugikan menuntut pembatalan perjanjian. Menurut Cohen, ${ }^{3}$ penggugat seharusnya mendalilkan bahwa perjanjian itu tidak ia kehendaki dalam bentuk yang demikian.

2. Asas Kesepakatan

Sebagaimana dalam asas kesepakatan dalam perjanjian, seperti

2 Penemuan Hukum dan Pemecahan Masalahnya, Mahkamah Agung Republik Indonesia, 1989, hal.87. terurai di aats maka asas konsensual ini atau asas kesepakatan merupakan asas yang universal dan sangat mutlak dalam suatu persetujuan. Undangundang tidak memberikan definisi tentang apa yang dimaksud dengan "sepakat para pihak".

Hofman dalam bukunya $\mathrm{R}$. Soetojo Prawirohamidjojo yang berjudul Hukum Perakitan mengemukakan bahwa dalam menjawab pertanyaan kapan terdapat kata sepakat maka perlu diketahui lebih dahulu "pernyataan kehendak" (Wilsverklaring) dari kedua belah pihak. Misalnya, dalam jual beli maka baik pembeli maupun penjual harus sama-sama menyatakan sikapnya dimana yang satu ingin menjual dan pihak yang lain ingin membeli.

Namun dianggap juga ada kesepakatan bila perjanjian diselesaikan atas persyaratan umum seperti perjanjian untuk angkutan udara, misalnya dimana seseorang yang menggunakan angkutan tersebut dianggap sepakat dengan syaratsyarat yang ditetapkan.

Begitu pula dengan perjanjian kredit perbankan dimana salah satu pihak atau nasabah dianggap sepakat kepada pihak bank diberi wewenang untuk menetapkan biaya atau bunga tanpa persetujuan dari pihak lain atau nasabah dengan ditandatanganinya perjanjian kredit tersebut.

3. Asas Itikad Baik

Dalam asas ini tegas dicantumkan dalam Pasal 1338 ayat (3) KUH Perdata bahwa persetujuan dilaksanakan dengan itikad baik.

Dalam kasus-kasus yang terjadi, pengertian itikad baik

${ }^{3}$ Ibid 
merupakan pertimbangan utama karena pemegang hak merek dari Indonesia bukan pemilik merek dari negara lain dikalahkan atas gugatan pemilik merek tersebut dengan pertimbangan bahwa merek atau produk tersebut sudah lama beredar di Indonesia dan karenanya harus dinyatakan sebagai pihak yang berhak menggunakan meek etrsebut, karena menurut pendirian Mahkamah Agung Republik Indonesia bahwa yang dimaksud oleh undang-undang dengan perkataan "pemakai pertama di Indonesia" harus ditafsirkan sebagai "pemakai pertama di Indonesia yang jujur (beritikad baik) sesuai dengan asas hukum, bahwa perlindungan diberikan kepada yang beritikad baik dan tidak kepada orang yang beritikad buruk. ${ }^{4}$

4. Asas Pacta Sunt Servanda dan Asas Kekuatan Berlaku Persetujuan

Dalam asas ini dengan tegas dicantumkan dalam Pasal 1338 ayat (1) KUH Perdata dan merupakan konsekwensi dari suatu hubungan hukum dengan segala akibat hukumnya.

Hal ini berkaitan pula dengan asas kepastian hukum yang dijamin oleh undang-undang. Selanjutnya dalam Pasal 1340 ayat (1) KUH Perdata ditetapkan bahwa persetujuan atau perjanjian hanya mengikat pihak-pihak yang membuatnya dan tidak mengikat pihak ketiga, kecuali bila perjanjian menentukan lain, artinya ada kepentingan pihak ketiga didalamnya.

5. Asas Kepatutan dan Kebiasaan

Didalam pergaulan masyarakat yang beradab maka

\footnotetext{
${ }^{4}$ Klopper Yurisprudensi Mahkamah Agung
} RI Tahun 1969-1984, hal.43. berlakunya suatu persetujuan atau perjanjian harus sesuai dengan kepatutan dan kebiasaan yang ebrlaku. Karenanya ditegaskan dalam Pasal 1339 KUH Perdata bahwa perjanjian yang bertentangan dengan kebiasaan bisa berakibat batal begitu pula bila suatu perjanjian dianggap tidak patut untuk ukuran masyarakat tertentu.

Asas-asas yang etrurai di atas merupakan syarat sahnya suatu eprjanjian. Dan hubungan hukum antara pemberi waralaba dan penerima waralaba dalam suatu perjanjian waralaba. Bahwa unsurunsur perjanjian waralaba saat ini hanya terdapat dalam ketentuanketentuan dalam Peraturan Pemerintah Republik Indonesia (PPRI) Nomor 16 Tahun 1997 jo Surat Keputusan Menteri Perindustrian dan Perdagangan Republik Indonesia Nomor 259.

Seperti diatur dalam Bab I Ketentuan Umum Pasal 1 Peraturan Pemerintah Republik Indonesia (PPRI) Nomor 16 Tahun 1997 bahwa

1. Waralaba adalah perikatan dimana salah satu pihak diberikan hak untuk memanfaatkan dan/atau menggunakan hak atau kekayaan intelektual atau penemuan atau ciri khas usaha yang dimiliki pihak lain dengan suatu imbalan berdasarkan persyaratan yang ditetapkan pihak lain tersebut, dalam rangka penyediaan barang dan/atau jasa. 
2. Pemberian waralaba adalah badan usaha atau perorangan yang memberi hak kepada pihak lain untuk memanfaatkan dan/atau menggunakan hak atau kekayaan intelektual atau penemuan atau ciri khas usaha yang dimiliki.

3. Penerima waralaba adalah badan usaha atau perorangan yang diberikan hak untuk memanfaatkan dan/atau menggunakan hak atas kekayaan intelektual atau penemuan atau ciri khas yang dimiliki pemberi waralaba.

Adapun Pasal 2 dari Peraturan Pemerintah tersebut berbunyi :

1. Waralaba diselenggarakan berdasarkan perjanjian etrtulis antara pemberi waralaba dan penerima waralaba.

2. Perjanjian waralaba dibuat dalam bahasa Indonesia dan terdapatnya berlaku hukum Indonesia.

Hanya tidak ditegaskan dalam Pasal 2 tersebut bahwa apakah perjanjian tertulis yang dimaksud dibuat di hadapan Notaris atau tidak.

Menurut penulis sebaiknya perjanjian waralaba dibuat dihadapan notaries karena kebanyakan pihak pemberi waralaba adalah perusahaan asing dan bentuk perjanjian lazimnya adalah perjanjian baku yang mencantumkan seluruh syarat dan ketentuan yang biasa mereka gunakan untuk perjanjian waralaba dalam suatu format tertentu dari negara asing.

\section{PERANAN \\ DALAM \\ PEMERINTAH \\ WARALABA (FRANCHISE)}

Perjanjian waralaba diterobos melalui salah satu asas dari hukum perjanjian yakni asas kebebasan berkontrak (Pasal 1388 KUH Perdata). Dimana asas kebebasan berkontrak adalah asas yang masih berlaku dan berada dalam sistem hukum negara kita, juga masih diakui keberadaannya di negara-negara lain.

Mengingat adanya jaminan tentang kebebasan membuat kontrak maka pihak-pihak merasa sangat penting dan merasa perlu sekali untuk mengatur dan menetapkan syaratsyarat dan ketentuan yang sesuai dengan apa yang dikehendakinya. Hal-hal demikian menyebabkan timbulnya suatu ketentuan-ketentuan yang standar yang dicantumkan dalam setiap perjanjian yang akhirnya dikenal sebagai perjanjian standar atau perjanjian baku.

Secara berurutan dapatlah dikatakan bahwa kebebasan berkontrak melahirkan suatu eprjanjian melahirkan perikatan yang oleh Pasal 1338 KUH Perdata, kekuatan mengikat dari perjanjian disebut pacta sunt servanda. Dengan demikian perjanjian baik yang lahir melalui proses negosiasi maupun perjanjian yang dibuat berdasarkan ketentuan yang sudah baku dan samasama mengikat.

Dalam perjanjian dengan proses negosiasi maka para pihak mempunyai kebebasan yang sama dalam menentukan isi dari perjanjian sehingga dicapai kata fairness.

Beda dengan apabila perjanjian disepakati atas dasar perjanjian baku yang sudah dipersiapkan oleh salah satu pihak, 
hingga pihak yang lain berada dalam posisi yang kurang menguntungkan karena harus memilih, diterima atau tidak.

Mengingat bahwa dalam usaha waralaba yang merupakan produk asing dengan format perjanjian yang biasanya sudah standar, maka bagi penerima waralaba lokal bentuk perjanjian semacam ini masih merupakan hal yang baru.

Di pihak Pemerintah, usaha waralaba penekanannya adalah pada produk yang diwaralabakan yaitu produk lokal dengan pengusahapengusaha lokal dimana hal ini akan sangat membantu bagi pengembangan usaha kecil dan menengah.

Di samping itu dengan diperbaruinya 3 (tiga) undang-undang mengenai hak milik intelektual seperti Undang-undang Hak Cipta, Paten dan Merek yang mengatur tentang pemberian lisensi dan suatu perjanjian maka lebih terbuka peluang untuk perkembangan usaha waralaba.

Seiring dengan itu seharusnya Pemerintah jauh-jauh hari sudah harus mempersiapkan undangundang khususnya waralaba dan tidak cukup hanya melalui Peraturan Pemerintah saja yang mengatur terbatas mengenai pendaftarannya saja.

Usaha-usaha lain yang bisa dilakukan oleh Pemerintah adalah untuk membuat ketentuan-ketentuan dan peraturan-peraturan mengenai suatu perjanjian untuk tidak selalu

5 Rudi Prasetya, Kedudukan Mandiri Perseroan Terbatas, Mandar Maju, 1995, hal.13. bersandar pada asas kebebasan berkontrak.

Peranan Pemerintah juga diperlukan untuk memberikan bimbingan kepada penerimaan waralaba lokal bila berhadapan dengan pemberi waralaba asing untuk melindungi waralaba lokal dari pasalpasal perjanjian yang tidak adil.

Namun dari segi tanggung jawab sebagai badan usaha hal tersebut penting mengingat usaha waralaba menyangkut kepentingan masyarakat hingga dapat dihindari hal-hal yang berugikan orang banyak. Lagi pula badan uaha dengan bentuk Perseroan Terbatas, mengingat tanggung jawabnya yang terbatas bisa melahirkan dorongan terhadap orangorang yang ingin menanamkan modalnya. ${ }^{5}$

Keuntungan lain dari bentuk Perseroan Terbatas adalah disamping mampu mengumpulkan modal juga berarti perkembangn perusahaan akan lebih baik karena dijalankan oleh direksi yang professional dan juga bisa menciptakan kesempatan kerja.

Peranan Pemerintah dalam turut menentukan batas-batas kebebasan berkontrak dalam perjanjian khususnya dalam perjanjian waralaba tidak hanya semata-mata melindungi kepentingan pihak yang lemah namun fungsi atau peranan hukum yang dilakukan oleh Pemerintah adalah untuk melindungi kepentingan semua pihak. Karenanya pengaturan perundang-undangan khususnya menyangkut perjanjian waralaba harus benar-benar mengatur tidak hanya untuk kepentingan pihakpihak dalam perjanjian waralaba tapi 
juga kepentingan dari masyarakat yang terkait dalam perjanjian tersebut dan juga kepentingan waralaba lanjutan serta konsumen.

\section{PENUTUP}

Pemerintah

belum mempunyai perangkat undangundang yang khusus mengatur perjanjian waralaba, sedangkan Peraturan Pemerintah Republik Indonesia (PPRI) Nomor 16 Tahun 1997 bukanlah peraturan dan ketentuan-ketentuan yang mengatur tentang usaha waralaba dan perjanjian waralaba melainkan pendaftarannya saja.

Peraturan perundangundangan waralaba yang seyogyanya harus dalam bentuk undang-undang harus memperhatikan peraturanperaturan yang sudah berlaku seperti Pasal 16, Pasal 17 dan Pasal 18 AB atau Peraturan Umum mengenai perundang-undangan untuk Indonesia, untuk tidak melahirkan peraturan yang bertentangan seperti yang terdapat dalam Pasal 2 ayat (2) Peraturan Pemerintah Republik Indonesia (PPRI) Nomor 16 Tahun 1997 khususnya yang memberlakukan hukum Indonesia dalam perjanjian waralaba.

\section{DAFTAR PUSTAKA}

Amir Karamoy, Sukses Usaha Lewat Waralaba, Jurnalindo Aksara Grafika, Jakarta, 1996, hal.3.

Juajir Sumardi, Aspek-aspek Hukum Franchise dan Perusahaan Transnasional, Hal.14

J. Douglas Queen, Pedoman Membeli dan Menjalankan Franchise, hal.4-5.

Penemuan Hukum dan Pemecahan Masalahnya, Mahkamah Agung Republik Indonesia, 1989, hal.87.

Klopper Yurisprudensi Mahkamah Agung RI Tahun 1969-1984, hal.43.

Rudi Prasetya, Kedudukan Mandiri Perseroan Terbatas, Mandar Maju, 1995, hal.13.

Herry .P Panggabean, Penyalahgunaan Keadaan Sebagai Alasan Untuk Pembatalan Perjanjian, Liberty, Yogyakarta, 1992, hal.40 